\title{
Studies on the Effects of Aerosolization on the Rates of Efflux of Ions from Populations of Escherichia coli Strain B
}

\author{
By J. D. ANDERSON* AND F. A. DARK \\ Microbiological Research Establishment, Porton, Salisbury, Wiltshire
}

(Accepted for publication 12 August 1966)

\begin{abstract}
SUMMARY
Potassium and phosphate were found to be the most suitable of the common ions for investigations into a possible correlation between ion movements and survival in populations recovered from aerosols of Escherichia coli strain B. Except at high relative humidities and short holding times, populations of $\left[{ }^{43} \mathrm{~K}\right]$-labelled $E$. coli lost practically all the radioisotope within a very short time after recovery from bacterial clouds. Very little $\left[{ }^{43} \mathrm{~K}\right]$ was removed from labelled bacteria by agitation in water or buffer solutions under conditions which simulated some of the stresses arising from the generation and collection of aerosols. Loss of potassium appeared to be a sequel of aerosolization, but was not in itself immediately lethal to the organisms. However, the results indicated that organisms which had been recovered from aerosols could not be regarded as unchanged rehydrated forms of the original bacteria. The pattern of phosphate efflux from $\left[{ }^{32} \mathrm{P}\right]-$ labelled organisms was quite different from the corresponding loss of potassium. A great deal of phosphate loss was due merely to the violent 'washing' procedures involved in the generation and collection of aerosols. Damage to ion-retention mechanisms may contribute to the decreased viability of organisms recovered from bacterial aerosols.
\end{abstract}

\section{INTRODUCTION}

Lethal processes in bacterial aerosols are of interest since the causative organisms of many diseases are transmitted in aerosols. Possible causes of loss of infectivity of aerosols of pathogenic bacteria may be inferred from the results of studies of factors which affect the survival of non-pathogenic organisms. Since the internal ionic environment of a bacterium is of fundamental importance in maintaining normal metabolic functions, the rate of efflux of various ions was measured from populations of Escherichia coli strain в both before aerosolization and immediately after recovery from aerosols. The purpose of these measurements was to detect changes in ion permeability or rates of exchange of ions and to establish whether any correlation existed between such changes and changes in the applied stress and survival of bacteria. Although many factors may affect survival in bacterial aerosols, this investigation was mainly concerned with the effects of relative humidity and holding time on aerosols maintained in the dark in a suitable apparatus (Anderson, 1966).

* Present address: The Medical School, University Walk, Bristol 2 


\section{METHODS}

Organism. Cultures of Escherichia coli strain B were maintained as described by Anderson (1966).

Media. Tryptone agar medium and a standard liquid tryptone medium (concentration of main ions in $\mu \mathrm{g} . / \mathrm{ml} .: \mathrm{K}, 400 ; \mathrm{Na}, 2480$; total $\mathrm{PO}_{4}, 1110$; inorganic $\mathrm{PO}_{4}, 800$; $\mathrm{Cl}, 2860$; total $\mathrm{SO}_{4}, 250$; inorganic $\mathrm{SO}_{4}, 135$ ) were described by Anderson (1966). For certain radiotracer experiments, isotopic uptake was increased by modification of the standard liquid tryptone medium to give smaller concentrations of either potassium (cations in $\mu \mathrm{g} . / \mathrm{ml} .: \mathrm{K}, 90 ; \mathrm{Na}, 2500$ ), sodium (cations in $\mu \mathrm{g} . / \mathrm{ml} .: \mathrm{Na}, 1100 ; \mathrm{K}, 1610$ ), phosphate (total phosphate $750 \mu \mathrm{g} . / \mathrm{ml}$.; inorganic phosphate $475 \mu \mathrm{g} . / \mathrm{ml}$.) or sulphate $\left(84 \mu \mathrm{g} . / \mathrm{ml}\right.$. total $\mathrm{SO}_{4} ; 20 \mu \mathrm{g} . / \mathrm{ml}$. inorganic $\left.\mathrm{SO}_{4}\right)$.

Phosphate + alginate buffer. $\mathrm{KH}_{2} \mathrm{PO}_{4}, 0.45 \% ;\left(\mathrm{NH}_{4}\right)_{2} \mathrm{SO}_{4}, 0.05 \% ; \mathrm{NH}_{4} \mathrm{Cl}, 0.05 \%$; sodium alginate (Manucol SS/LH by Alginate Industries Ltd., London W.C.2), $0 \cdot 25 \% ; \mathrm{NaOH}$ to $\mathrm{pH} 7 \cdot 2$, approximately $0 \cdot 1 \%$. Apart from a few special cases, this fluid was used for the recovery of organisms from aerosols and for serial dilution of most bacterial samples. The alginate was incorporated to decrease losses of organisms by physical processes (Henderson, 1952).

Gelatine saline. $\mathrm{NaCl}, 0.5 \%$; gelatine, $0 \cdot 1 \% ; \mathrm{pH} \mathrm{7.2}$. This fluid was used as an alternative to phosphate + alginate buffer for serial dilutions and the collection of certain aerosol samples.

Radiochemicals. These were supplied by The Radiochemical Centre, Amersham, Buckinghamshire. Carrier free $\left[{ }^{43} \mathrm{~K}\right]$ was obtained as the chloride in approximately $0.001 \mathrm{~N}$-hydrochloric acid. [ ${ }^{24} \mathrm{Na}$ ] was provided as unprocessed irradiated sodium chloride of specific activity $350 \mathrm{mc} / \mathrm{g}$. [ $\left.{ }^{32} \mathrm{P}\right]$ was obtained as the orthophosphate in dilute hydrochloric acid solution; specific activity $41 \cdot 5 \mathrm{c} . / \mathrm{mg}$. Carrier-free $\left[{ }^{35} \mathrm{~S}\right]$ was supplied as the sulphate in aqueous solution.

Measurement of radioactivity. Solutions containing $\left[{ }^{35} \mathrm{~S}\right]$ and $\left[{ }^{32} \mathrm{P}\right]$ were determined by a 'coincidence' scintillation counting technique by using apparatus which had previously been used for $\left[{ }^{14} \mathrm{C}\right]$ assay (Anderson \& Smith, 1965). The isotopes $\left[{ }^{24} \mathrm{Na}\right]$ and $\left[{ }^{43} \mathrm{~K}\right]$ were assayed in a solid crystal scintillation counter (bench scintillation counter no. 6006 and scaler no. 1700 by Isotope Developments Ltd., Reading, Berkshire). Suspensions or solutions ( $3 \mathrm{ml}$.) were placed in $5 \mathrm{ml}$. disposable polythene pots with snap-on lids (catalogue no. XT 1580; X-Lon Products Ltd., London, S.W.1).

Determination of cations by flame photometry. Sodium and potassium were estimated with an E.E.L. flame photometer (Evans Electroselenium Ltd., Halstead, Essex). Bacterial suspensions were heated at $100^{\circ}$ for $10 \mathrm{~min}$. before ion estimation. The apparatus was calibrated with standard solutions which contained appropriate amounts of ions which might interfere with determinations.

Determination of phosphorus, chloride and sulphate. Phosphorus was determined by the method of King (1932), chlorides by titration with silver nitrate and potassium thiocyanate and sulphates by gravimetric estimation as barium sulphate.

Dry-weight determinations. A measured volume (about $5 \mathrm{ml}$. containing $10^{11}$ organisms) of bacterial suspension was centrifuged and the deposit washed once with formol saline (sodium chloride, $0.85 \%(\mathrm{w} / \mathrm{v})$; formalin $3 \%(\mathrm{v} / \mathrm{v})$ ). After one wash with water, the bacterial pellet was dried $\left(100^{\circ}\right.$ for $\left.16 \mathrm{hr}\right)$ and weighed.

Growth of radiolabelled suspensions of Escherichia coli, strain B. All suspensions 
were grown by shake culture in liquid media at $37^{\circ}$ and stored at room temperature for $2-5 \mathrm{hr}$ before use. An inoculum of $5 \times 10^{7}$ organisms $/ \mathrm{ml}$. provided a resting phase suspension containing about $10^{10}$ organisms $/ \mathrm{ml}$. after overnight $(16 \mathrm{hr})$ growth. $\left[{ }^{43} \mathrm{~K}\right]$-labelled bacterial suspensions of low specific activity were obtained by overnight growth in the standard tryptone medium supplemented with $40 \mu \mathrm{c}$. $/ \mathrm{ml}$. of radiotracer. $\left[{ }^{43} \mathrm{~K}\right]$-labelled organisms of high specific activity were prepared by overnight growth in standard tryptone medium; the organisms were separated from the residual medium by centrifugation then resuspended as a dense suspension $\left(2 \times 10^{10}\right.$ organisms $/ \mathrm{ml}$. $)$ in a 'low potassium' tryptone medium containing the radiotracer $(30 \mu \mathrm{c} . / \mathrm{ml}$.; $90 \mu \mathrm{g} . \mathrm{K} /$ ml.). This suspension was then re-incubated in a shake flask $\left(90 \mathrm{~min}\right.$. at $\left.37^{\circ}\right)$ and stored for $1-5 \mathrm{hr}$ at room temperature before use. [ ${ }^{24} \mathrm{Na}$-labelled organisms were prepared by overnight growth in normal or 'low sodium' media supplemented with radiotracer $(10 \mu \mathrm{c} . / \mathrm{ml}$.).

$\left.{ }^{32} \mathrm{P}\right]$-labelled bacterial suspensions were obtained by overnight growth in normal or 'low phosphate' media containing radiotracer $10 \mu \mathrm{c} . / \mathrm{ml}$. Overnight growth in a 'low sulphate' medium containing radiotracer $10 \mu \mathrm{c} . / \mathrm{ml}$. provided [ ${ }^{35} \mathrm{~S}$ ]-labelled bacterial suspensions.

Determination of bacterial survival values. Viability was defined as the ability to produce a visible colony on tryptone agar in $18 \mathrm{hr}$. Total bacterial numbers recovered from aerosols were calculated from the radiotracer content of impinger samples and the viable and radiotracer content of unsprayed suspensions. Unsprayed suspensions were given a nominal viability of $100 \%$. Plate counts and radiotracer determinations were so arranged that survival estimates generally had a $95 \%$ confidence belt of better than $\pm 10 \%$ of observed values.

Apparatus for the study of bacterial aerosols. The technique and apparatus used have already been described (Anderson, 1966). Aerosols were stored in a rotating drum (Goldberg, Watkins, Boerke \& Chatigny, 1958) and were recovered over a period of 1 min. into sonic impingers (raised Porton impinger; May \& Harper, 1957) containing either phosphate + alginate buffer or gelatine saline (12 ml.; in duplicate). Impinger samples contained about $3 \times 10^{6}$ organisms $/ \mathrm{ml}$. (equiv. $0 \cdot 15 \mu \mathrm{g}$. dry wt organism $/ \mathrm{ml}$.)

Preparation of bacterial samples for aerosolization and ion analysis. The bacterial pellet obtained by centrifugation of cultures was quickly washed with water by centrifugation and prepared as a suspension in water containing about $4 \times 10^{9}$ organisms $/ \mathrm{ml}$. Radiotracer and ion determinations were made on appropriate suspensions and supernatant fluids to determine the extent of incorporation of the various ions and the amounts removed on washing.

Determination of $\left[{ }^{32} \mathrm{P}\right]$ and $\left[{ }^{43} \mathrm{~K}\right]$ loss from populations of washed radiolabelled Escherichia coli strain $B$. Bacterial suspensions recovered from aerosols were quickly filtered through a membrane filter (Millipore PHWP) $1 \mathrm{~min}$. after the conclusion of sampling and at intervals of 14 and 29 min. thereafter (nominal 2, 15 and $30 \mathrm{~min}$. samples). The efflux of radiotracer at each sampling time was obtained by subtraction of the radiotracer content of the filtrates from that of the original unfiltered bacterial suspension. Suspensions removed from the spray pot before and after each experiment were diluted $1 / 1000$ in the appropriate collecting fluid to measure the rate of loss of tracer from non-stressed organisms at a bacterial concentration similar to that of the samples recovered from aerosols. After 2, 15 and $30 \mathrm{~min}$., portions of these diluted 
suspensions were filtered to measure the rate of efflux of radiotracer. Estimates of the $\left[{ }^{43} \mathrm{~K}\right]$ and $\left[{ }^{32} \mathrm{P}\right]$ content of labelled bacteria had $95 \%$ fiducial limits of the order of $\pm 5 \%$.

\section{RESULTS}

Survey of the suitability of common ions and growth procedures for permeability studies with Escherichia coli strain $B$

The small bacterial samples $\left(10^{6}-10^{7}\right.$ organisms $/ \mathrm{ml}$; equivalent to about $10^{-6}-10^{-7} \mathrm{~g}$. dry wt. organisms/ml. suspension) which may be recovered from aerosols in conventional apparatus prevented the use of ordinary assay methods and limited investigations to those ions with suitable radioactive isotopes. In a preliminary survey, the rates of efflux of a number of common ions from dense $\left(10^{10}\right.$ organisms $/ \mathrm{ml}$.) suspensions of Escherichia coli was measured by radiotracer methods. Ions were identified which were normally retained in non-stressed organisms and which would

Table 1. Radioactive ion uptake and loss of suspensions of various cultures of Escherichia coli strain $B$

\begin{tabular}{|c|c|c|c|c|}
\hline $\begin{array}{l}\text { Period of } \\
\text { incorporation } \\
\text { of isotope }\end{array}$ & Growth medium & Ion & $\begin{array}{l}\text { Uptake of } \\
\text { labelled ion } \\
\text { (\% amount } \\
\text { added to } \\
\text { growth medium) }\end{array}$ & $\begin{array}{l}\text { Amount of } \\
\text { labelled ion } \\
\text { remaining in } \\
\text { organisms after } \\
\text { one wash with } \\
\text { water ( } \% \text { amount } \\
\text { added to } \\
\text { growth medium) }\end{array}$ \\
\hline \multirow[t]{2}{*}{$16 \mathrm{hr}$} & Standard tryptone & {$\left[{ }^{24} \mathrm{Na}\right]$} & $\begin{array}{c}\text { Below } \\
\text { measurable } \\
\text { limits }\end{array}$ & - \\
\hline & & $\begin{array}{l}{\left[{ }^{43} \mathrm{~K}\right]} \\
{\left[{ }^{32} \mathrm{PO}_{4}\right]} \\
{\left[{ }^{35} \mathrm{SO}_{4}\right]}\end{array}$ & $\begin{array}{c}7 \cdot 6 \\
33 \\
\text { Below } \\
\text { measurable } \\
\text { limits }\end{array}$ & $\begin{array}{c}3 \cdot 4 \\
27 \\
-\end{array}$ \\
\hline $16 \mathrm{hr}$ & 'Low sodium' tryptone & {$\left[{ }^{24} \mathrm{Na}\right]$} & $2 \cdot 4$ & $0 \cdot 3$ \\
\hline $90 \mathrm{~min}$. & $\begin{array}{l}16 \mathrm{hr} \text { growth in normal tryptone followed } \\
\text { by incubation for } 90 \mathrm{~min} \text {. in 'low } \\
\text { potassium' tryptone }\end{array}$ & {$\left[{ }^{43} \mathrm{~K}\right]$} & 64 & 55 \\
\hline $16 \mathrm{hr}$ & 'Low phosphate' tryptone & {$\left[{ }^{32} \mathrm{PO}_{\mathrm{d}}\right]$} & 52 & 43 \\
\hline $16 \mathrm{hr}$ & 'Low-sulphate' tryptone & {$\left[{ }^{35} \mathrm{SO}_{4}\right]$} & $2 \cdot 6$ & $0 \cdot 2$ \\
\hline
\end{tabular}

therefore be suitable indicators of changes in permeability or rates of internal-external ion exchange. Considerations of cost and safety limited investigations to $\left[{ }^{43} \mathrm{~K}\right]$, $\left[{ }^{24} \mathrm{Na}\right],\left[{ }^{32} \mathrm{PO}_{4}\right]$ and $\left[{ }^{35} \mathrm{SO}_{4}\right]$. Results summarized in Table 1 show that the uptake of the various radiotracers could be improved by modification of the standard liquid tryptone medium. Sodium and sulphate were obviously unsuitable for study since they were easily washed out from non-stressed bacteria. Phosphate efflux studies were all made with organisms grown on a medium of decreased phosphate content. Uptake of $\left[{ }^{43} \mathrm{~K}\right]$ by organisms which had been grown overnight in normal tryptone medium was extremely low. The low specific activity of organisms which had been grown in this manner made radiotracer determinations inaccurate and the waste of large quantities of $\left[{ }^{43} \mathrm{~K}\right]$ in the residual medium was expensive and hazardous. However, 
uptake of the radiolabel was improved, and the potassium content of the organism increased from 0.12 to $0.58 \%$ (dry weight) by re-incubation of a concentrated suspension of washed organisms in fresh $\left[{ }^{43} \mathrm{~K}\right]$-labelled medium of decreased potassium content.

\section{Effect of relative humidity and holding time in the aerosol on the rate of loss of $\left[{ }^{43} \mathrm{~K}\right]$ by Escherichia coli strain $B$}

As mentioned above, this work was largely done with bacterial suspensions which had been re-incubated in fresh medium to increase the specific activity of the radiolabel. Aerosols generated from washed bacterial suspensions were stored at various relative humidities. At each relative humidity value, bacterial samples were recovered from the aerosol cloud $1.2 \mathrm{sec}$., $5 \mathrm{~min}$. and $30 \mathrm{~min}$. after generation of the cloud. For

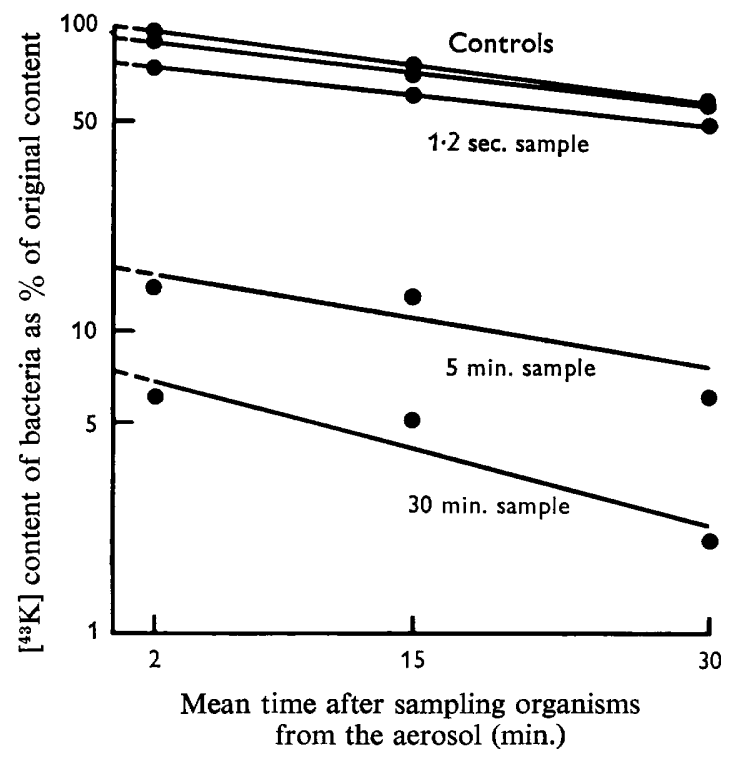

Fig. 1. The efflux of $\left[{ }^{43} \mathrm{~K}\right]$ from labelled populations of Escherichia coli strain B as a function of time after generation of aerosol, and of time after sampling of the bacterial population from an aerosol held at a relative humidity of $95 \%$. The plots represent (reading downwards) efflux from 'control' samples removed from the spray pot before, then after the experiment, then samples recovered from aerosols at $1.2 \mathrm{sec}$., $5 \mathrm{~min}$. and $30 \mathrm{~min}$. after generation.

each bacterial sample collected from the aerosol the $\left[{ }^{43} \mathrm{~K}\right]$ content of the organisms was determined at 2, 15 and $30 \mathrm{~min}$. after the mean time of sampling. The plot of $\log \left[{ }^{43} \mathrm{~K}\right]$ content against time for these three points $(2,15,30 \mathrm{~min}$.) showed excellent linearity in nearly all instances. Figure 1 illustrates the results of a single typical experiment. A Ferranti Meteor-Mercury computer was programmed to return the slopes $\left(\log \%\left[{ }^{43} \mathrm{~K}\right]\right.$-content organisms against time) and intercepts for 13 experiments. Since the radiotracer content of the bacterial populations was calculated from the difference between the observed radiotracer values of filtered and non-filtered bacterial suspensions, the statistically acceptable scatter in radiotracer determinations sometimes resulted in apparent losses of over $100 \%$ of the original radiotracer.

The $\left[{ }^{43} \mathrm{~K}\right]$ content of bacteria which had been recovered from aerosols could not 
generally be conveniently measured at less than 2 min. after the mean time of collection. However, values for the $\left[{ }^{43} \mathrm{~K}\right]$ content of bacterial populations $30 \mathrm{sec}$. after collection from the aerosol were similar to values obtained at $2 \mathrm{~min}$. Likewise the $\left[{ }^{43} \mathrm{~K}\right]$ content of non-sprayed suspensions was similar at $10 \mathrm{sec}$. and at $2 \mathrm{~min}$. after dilution with collecting fluid. The intercept or 'initial' value of potassium efflux was thus a measure of the extent of loss or exchange of internal potassium with the collecting fluid in a period of probably less than 10-30 sec. after recovery from the aerosol. Increases in 'initial' potassium efflux values imply increases in bacterial permeability or damage to other ion retention mechanisms.

The 'initial' loss of $\left[{ }^{43} \mathrm{~K}\right]$ from aqueous bacterial suspensions which were merely diluted in phosphate + alginate buffer collecting fluid was only $5.8 \%$ (mean of thirteen determinations). The corresponding figure $(8.3 \%$ ) for organisms recovered from the spray pot at the conclusion of experiments, and which had suffered violent agitation in water for $3 \mathrm{~min}$., was similar. Agitation of washed bacterial suspensions
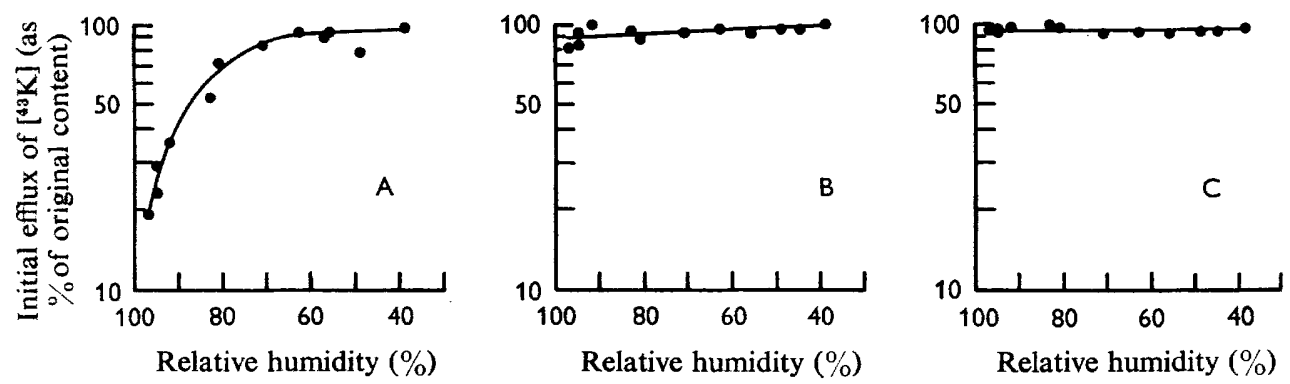

Fig. 2. The effect of relative humidity and holding time in the aerosol on the 'initial' efflux of $\left[{ }^{43} \mathrm{~K}\right]$ from labelled populations of Escherichia coli strain B. A, B and C represent, respectively, results obtained with populations recovered from aerosols at $1.2 \mathrm{sec}$., $5 \mathrm{~min}$. and $30 \mathrm{~min}$. after generation.

in water thus had little effect on the initial $\left[{ }^{43} \mathrm{~K}\right]$ efflux from this organism. Figure 2 shows that organisms recovered from aerosols at relative humidities ranging from 39 to $97 \%$ suffer a much larger loss of $\left[{ }^{43} \mathrm{~K}\right]$ than the controls $(5 \cdot 8 \%$ and $8 \cdot 3 \%)$. For samples recovered from aerosols $1.2 \mathrm{sec}$. after generation there was a highly significant negative correlation $(P=0.1 \%)$ between relative humidity and initial potassium loss (correlation coefficient $=-0.92$ ). For bacterial populations recovered from aerosols $5 \mathrm{~min}$. and $30 \mathrm{~min}$. after generation the corresponding correlation coefficients were still negative, although smaller $(-0 \cdot 26$ and $-0 \cdot 16$, respectively) and not significant $(P>10 \%)$. 'Initial' $\left[{ }^{43} \mathrm{~K}\right]$ losses in samples recovered from aerosols after $1.2 \mathrm{sec}$. were much higher than the two controls in all 12 experiments; losses after 5 and $30 \mathrm{~min}$. were invariably greater than after $1.2 \mathrm{sec}$. 'Initial' $\left[{ }^{43} \mathrm{~K}\right.$ ] losses in samples recovered from aerosols after 5 and $30 \mathrm{~min}$. were mainly in the $90 \%$ region and differences between losses at these two sampling times were therefore not pronounced.

The large initial loss of radiotracer from populations recovered from aerosols could not have been due to mechanical stresses involved in the generation and collection of aerosols since the extent of the effect was dependent upon the relative humidity and holding time in the aerosol cloud. The negligible increase $(1.8 \%)$ in the 'initial' loss of radiotracer when organisms recovered from the spray pot were diluted in phosphate + 
alginate buffer and then violently aerated in an impinger for $1 \mathrm{~min}$. provided further evidence that these mechanical stresses were unimportant.

If loss of $\left[{ }^{43} \mathrm{~K}\right]$ were a controlled exchange process instead of a net loss, then increases in $\left[{ }^{43} \mathrm{~K}\right]$ efflux would not be of such significance as a measure of the failure of ion control mechanisms. This possibility was disproved by collecting a representative array of aerosol samples into gelatine saline; this collecting fluid is free from potassium and gives survival values only slightly inferior to those obtained with phosphate + alginate buffer. Results summarized in Table 2 show that $\left[{ }^{43} \mathrm{~K}\right]$ efflux into gelatine saline was only a little lower than into the normal collecting fluid. This confirms that, following recovery of this organism from aerosols, there was a loss of control over mechanisms responsible for potassium retention.

Table 2. The effect of relative humidity and holding time in the aerosol on the loss of $\left[{ }^{43} \mathrm{~K}\right]$ by labelled populations of Escherichia coli strain $B$, sprayed into air and collected into gelatine saline

$\begin{array}{cccc}\begin{array}{c}\text { Relative } \\ \text { humidity } \\ (\%)\end{array} & \begin{array}{r}\text { 'Initial'* loss of }\left[{ }^{43} \mathrm{~K}\right] \text { (as \% original radiotracer content) } \\ \text { from bacterial populations recovered from aerosol clouds } \\ \text { at various times after generation: }\end{array} \\ 45 & 1 \cdot 2 \mathrm{sec} . & 96(98) & 30 \mathrm{~min} . \\ 71 & 91(95) & 94(94) & 93(94) \\ 94 & 84(84) & 68(89) & 85(92) \\ & 23(29) & & 86(94)\end{array}$

* Comparable figures for populations collected into phosphate + alginate buffer are shown in parentheses. Mean values for 'initial' $\left[{ }^{43} \mathrm{~K}\right]$ efflux from non-aerosolized populations sampled from the spray pot before and after each experiment were $6.4 \%(5 \cdot 8)$ and $6.5 \%(8 \cdot 3)$, respectively.

Table 3. The effect of relative humidity and holding time in the aerosol on the loss of $\left[{ }^{43} \mathrm{~K}\right]$ by labelled populations of Escherichia coli strain $B$, sprayed into nitrogen and collected into phosphate alginate buffer

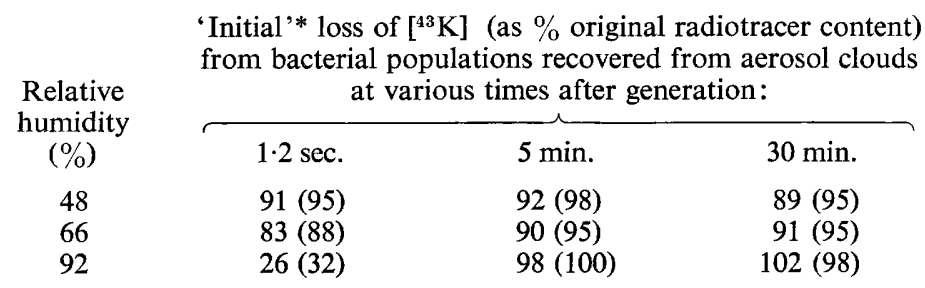

* Comparable figures for populations recovered from an atmosphere of air are shown in parentheses. Mean values for 'initial' efflux from non-aerosolized populations sampled from the spray pot before and after each experiment were $5.7 \%(5 \cdot 8)$ and $7 \cdot 6 \%(8 \cdot 3)$, respectively.

The enhanced survival of aerosols of Escherichia coli strain B, and of other organisms, in an atmosphere of nitrogen has been attributed to a toxic action of oxygen (Ferry, Brown \& Damon, 1958; Hess, 1965; Cox, 1966). The rate of efflux of $\left[{ }^{43} \mathrm{~K}\right]$ was determined from organisms which had been aerosolized into an atmosphere of nitrogen, in order to detect whether ion efflux was affected by the absence of oxygen. Results given in Table 3 show that the extent of the 'initial' $\left[{ }^{43} \mathrm{~K}\right]$ efflux from bacteria recovered from aerosols which had been stored in nitrogen was similar to that from aerosols stored in air. 
Small variations in growth conditions may often have a marked effect on bacterial survival in aerosols. 'Resting phase' populations were used for the phosphate efflux studies described below and for past investigations of the biochemical properties of organisms recovered from bacterial aerosols (Anderson, 1966). To prove that $\left[{ }^{43} \mathrm{~K}\right]$ efflux phenomena described for 're-incubated' organisms were not unique to the particular growth conditions, comparative studies were made of resting-phase populations over a representative array of holding times and relative humidities. The low specific activity of the resting-phase organisms widened the usual fiducial limits for $\left[{ }^{43} \mathrm{~K}\right]$ loss from $\pm 5 \%$ to about $\pm 20 \%$ in these particular experiments. Results summarized in Table 4 show that although $\left[{ }^{43} \mathrm{~K}\right]$ loss from non-stressed resting-phase organisms was greater than from 're-incubated' bacteria under similar conditions, the large initial loss of tracer, and the general dependance of this initial loss on relative humidity and holding time, was similar for populations grown under either condition.

Table 4. Effect of relative humidity and holding time in the aerosol on the loss of $\left[{ }^{43} \mathrm{~K}\right]$ by labelled populations recovered from aerosols generated from resting-phase suspensions of Escherichia coli strain $B$

\begin{tabular}{|c|c|c|c|}
\hline \multirow{2}{*}{$\begin{array}{l}\text { Relative } \\
\text { humidity } \\
\quad(\%)\end{array}$} & \multicolumn{3}{|c|}{$\begin{array}{l}\left.\text { 'Initial' }{ }^{*} \text { loss of }{ }^{[93} \mathrm{K}\right] \text { (as } \% \text { original radiotracer content } \\
\text { from bacterial populations recovered from aerosol cloud } \\
\text { at various times after generation: }\end{array}$} \\
\hline & $1.2 \mathrm{sec}$ & $5 \mathrm{~min}$. & $30 \mathrm{~min}$. \\
\hline 34 & $103(94)$ & $120(102)$ & $111(96)$ \\
\hline 36 & $96(94)$ & $101(101)$ & $99(96)$ \\
\hline 70 & $97(94)$ & $100(94)$ & $102(95)$ \\
\hline 71 & $97(84)$ & $95(94)$ & $80(95)$ \\
\hline 89 & $62(55)$ & - & $107(95)$ \\
\hline 92 & $53(36)$ & $92(90)$ & $86(98)$ \\
\hline
\end{tabular}

* Comparable figures for populations derived from 're-incubated' cultures are shown in parenthese. Mean values for 'initial' efflux from non-aerosolized populations sampled from the spray pot before and after each experiment were $19.9 \%(5 \cdot 8)$ and $39.4 \%(8 \cdot 3)$, respectively.

\section{Effect of relative humidity and holding time in the aerosol on the survival of ${ }^{\left[{ }^{43} \mathrm{~K}\right]}$-labelled populations of Escherichia coli strain $B$}

Figure 3 summarizes the effect of relative humidity and holding time in the aerosol on the survival of Escherichia coli strain B aerosols generated from washed suspensions. of cultures which had been re-incubated for $90 \mathrm{~min}$. in a medium of decreased potassium content. The corresponding figures for the survival of lag-phase organisms were generally lower and similar to those of Anderson (1966). There does not appear to be any simple correlation between changes in viability and the extent of $\left[{ }^{43} \mathrm{~K}\right]$ efflux shown in Fig. 2.

\section{The effect of relative humidity and holding time in the aerosol on the} rate of loss of $\left[{ }^{32} P\right]$ by Escherichia coli strain $B$

Aerosols were generated from washed suspensions of resting-phase cultures of Escherichia coli strain B which had been grown in a medium of decreased phosphate content. The 'initial' or 'intercept' values for [ $\left.{ }^{32} \mathrm{P}\right]$ efflux were calculated in a similar way to the comparable figure for $\left[{ }^{43} \mathrm{~K}\right]$ efflux. The loss of $\left[{ }^{32} \mathrm{P}\right]$ from populations recovered from aerosols, and from non-stressed populations, in a single typical ex- 
periment is shown in Fig. 4 (note the enlargement of the $y$ scale as compared to Fig. 1). The pattern of loss of phosphate was obviously quite different to that of loss of $\left[{ }^{43} \mathrm{~K}\right]$.

Results summarized in Table 5 show that the 'initial' [ $\left.{ }^{32} \mathrm{P}\right]$ loss appeared to be independent of the relative humidity of the bacterial cloud, and only showed a small increase with increasing aerosol age. The large increase in the value of the 'initial'

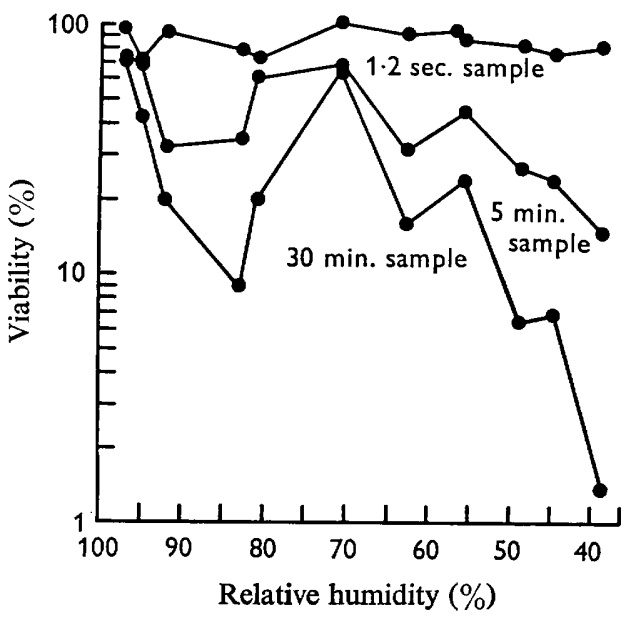

Fig. 3

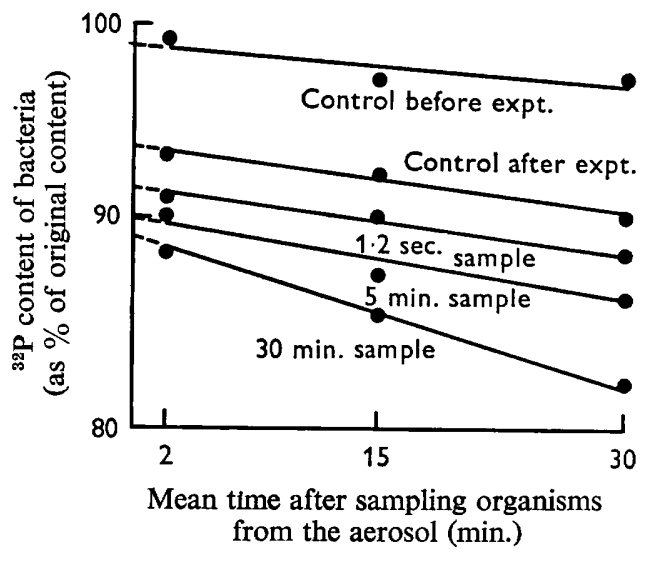

Fig. 4

Fig. 3. Viability of populations of Escherichia coli strain B recovered from aerosols at $1.2 \mathrm{sec} ., 5 \mathrm{~min}$. and $30 \mathrm{~min}$. (reading plots downwards) after generation of aerosol.

Fig. 4. The efflux of $\left[{ }^{32} \mathrm{P}\right]$ from labelled populations of Escherichia coli strain B, as a function of time after generation of aerosol and of time after sampling of bacterial population from an aerosol stored at a relative humidity of $70 \%$. The plots represent (reading downwards) efflux from 'control' samples recovered from the spray pot before, then after each experiment, then samples recovered from aerosols at $1.2 \mathrm{sec}$., $5 \mathrm{~min}$. and $30 \mathrm{~min}$. after generation.

\section{Table 5. The effect of relative humidity and holding time in the aerosol on the} efflux of $\left[{ }^{32} P\right]$ from labelled populations of Escherichia coli strain $B$

'Initial'* loss of [ $\left.{ }^{32} \mathrm{P}\right]$ (as \% original radiotracer content)

$\begin{array}{cccc}\begin{array}{c}\text { Relative } \\ \text { humidity } \\ (\%)\end{array} & \begin{array}{c}\text { from bacterial populations recovered from aerosol clouds } \\ \text { at various times after generation: }\end{array} \\ 36 & 1 \cdot 2 \mathrm{sec} . & 5 \mathrm{~min} . & 30 \mathrm{~min} . \\ 44 & 11 & 11 & 13 \\ 53 & 12 & 10 & 14 \\ 55 & 8 & 8 & 9 \\ 70 & 10 & 17 & 7 \\ 78 & 9 & 10 & 11 \\ 84 & 6 & 10 & 13 \\ 89 & 10 & 16 & 14 \\ 93 & 11 & 14 & 12 \\ & 14 & 14 & 16\end{array}$

* Mean values for 'initial' [ $\left.{ }^{32} \mathrm{P}\right]$ efflux for non-aerosolized populations sampled from the spray pot before and after each experiment were $1.2 \%$ and $7 \cdot 4 \%$, respectively. 
phosphate loss following agitation of the bacterial suspension in the spray device during the course of each experiment, suggests that a great deal of this ion was removed from the organism merely by agitation with water. Agitation of organisms for $1 \mathrm{~min}$. in phosphate + alginate buffer in an aerosol collection device caused an exchange or loss of $\left[{ }^{32} \mathrm{P}\right]$ approaching that from samples which had been recovered from the aerosol $1.2 \mathrm{sec}$. after its generation. A high proportion of $\left.{ }^{32} \mathrm{P}\right]$ efflux can thus be accounted for as a sequel of the vigorous 'washing' processes involved in the generation and collection of aerosols.

\section{The effect of relative humidity and holding time in the aerosol on the survival of $\left[{ }^{32} P\right]$-labelled populations of Escherichia coli strain $B$}

The response of $\left.{ }^{[2} \mathrm{P}\right]$-labelled populations of Escherichia coli strain B to variations of relative humidity and holding time in aerosols was similar to that described by Anderson (1966) for non-labelled populations. There was no simple correlation between survival and the extent of $\left[{ }^{32} \mathrm{P}\right]$ efflux (Table 5).

\section{DISCUSSION}

The high and generally complete loss of potassium by populations of Escherichia coli strain B immediately after recovery from aerosol clouds obviously prevents any attempt to establish a simple correlation between potassium loss and survival. Organisms recovered from bacterial clouds may, under certain conditions, lose most of their potassium and yet be substantially viable. Loss of control of potassium metabolism is not therefore in itself immediately lethal to the organisms provided that these are eventually returned to a medium containing adequate potassium. However, these potassium efflux studies do suggest that after recovery from aerosols $E$. coli is biochemically, and probably physically, quite different to the non-stressed organism. Therefore one cannot regard organisms which have been recovered from aerosols merely as unchanged rehydrated forms of the original bacteria. Furthermore, loss of control of potassium implies a possible derangement of bacterial processes which control the metabolism of other ions and substrates.

Populations of Escherichia strain B show a severe decrease in ability to synthesize inducible protein immediately after recovery from aerosol clouds (Anderson, 1966). This decreased rate of protein synthesis might well be due to the disruption of potassium ion control, since there is evidence that potassium ion is responsible for normal ribosomal function in a mutant of $E$. coli (Ennis \& Lubin, 1965) and in Aerobacter aerogenes (Tempest, Dicks \& Hunter, 1966). The decreased rate of protein synthesis might also be explained by the finding that a particular ratio of monovalent ions to magnesium is necessary for the correct functioning of ribosomes from $E$. coli (Cammack \& Wade, 1965). Besides affecting protein synthesis, disturbances of potassium ion metabolism might affect the many enzymes for which this ion is a co-factor, especially those involved in carbohydrate and aromatic compound metabolism.

The rates of efflux of phosphate and potassium ions following stress in the aerosol are fundamentally different. A great deal of the $\left[{ }^{32} \mathrm{P}\right]$ present in Escherichia coli is bound to high molecular weight organic compounds and would obviously be unable to leave the organism before extensive damage had occurred. Although potassium efflux appears to be a direct sequel of aerosolization, much of the loss of phosphate 
is due to a mere 'washing out' of this anion. No attempt was made to determine the chemical nature of $\left[{ }^{32} \mathrm{P}\right]$ lost from organisms recovered from aerosols, because of technical difficulties. If suitable techniques could be developed, a knowledge of the effect of various stresses in the aerosol on the efflux of organic phosphorus compounds might provide further information on the changes in metabolism and ion control resulting from aerosolization.

We are grateful to Mr I. H. Silver for help and encouragement, to Mr S. Peto for statistical analysis and advice and to $\mathrm{Mr} \mathrm{G}$. Crouch for experimental assistance.

\section{REFERENCES}

Anderson, J. D. (1966). Biochemical studies of lethal processes in aerosols of Escherichia coli. J. gen. Microbiol. 45, 303.

Anderson, J. D. \& SMITH, H. (1965). The metabolism of erythritol by Brucella abortus. J. gerl. Microbiol. 38, 109.

CAmmack, K. A. \& WADE, H. E. (1965). The sedimentation behaviour of ribonuclease-active and -inactive ribosomes from bacteria. Biochem. J. 96, 671.

Cox, C. S. (1966). The survival of Escherichia coli when atomized into air and into nitrogen from distilled water and from protecting agents, as a function of relative humidity. J. gen. Microbiol. 44, 333.

ENNIS, H. L. \& LubIN, M. (1965). Pre-ribosomal particles formed in potassium-depleted cells. Studies on degradation and stabilization. Biochim. biophys. Acta 95, 605 .

FERrY, R. M., Brown, W. F. \& Damon, E. B. (1958). Studies of the loss of viability of bacterial aerosols. III. Factors affecting death rates of certain non-pathogens. J. Hyg., Camb. 56, 389.

GoldberG, L. J., Watkins, H. M. S., Boerke, E. E. \& Chatigny, M. A. (1958). The use of a rotating drum for the study of aerosols over extended periods of time. Am. J. Hyg. 68, 85 .

Henderson, D. W. (1952). An apparatus for the study of airborne infection. J. Hyg., Camb. $50,53$.

Hess, G. E. (1965). Effect of oxygen on aerosolized Serratia marcescens. Appl. Microbiol. $13,781$.

KING, E. J. (1932). The colorimetric determination of phosphorus. Biochem. J. 26, 292.

MAY, K. R. \& HARPER, G. J. (1957). The efficiency of various liquid impinger samplers in bacterial aerosols. Br. J. ind. Med. 14, 287.

Tempest, D. W., Dicks, J. W. \& Hunter, J. R. (1966). The inter-relationship between potassium, magnesium and phosphorus in potassium limited chemostat cultures of Aerobacter aerogens. J. gen. Microbiol. 45, 135. 